\title{
Two new species and new records of biting midges of the genus Culicoides from northwestern Argentina (Diptera: Ceratopogonidae)
}

\author{
Gustavo Ricardo Spinelli ${ }^{1 /+}$, Cecilia Veggiani Aybar², María Julia Dantur Juri ${ }^{2,3}$, \\ Mercedes Lizarralde de Grosso ${ }^{2}$, Pablo Ignacio Marino ${ }^{1}$ \\ División Entomología, Museo de La Plata, La Plata, Argentina ${ }^{2}$ nnstituto Superior de Entomología Dr Abraham Willink, \\ Facultad de Ciencias Naturales e Instituto Miguel Lillo, Universidad Nacional de Tucumán, Tucumán, Argentina \\ ${ }^{3}$ Instituto de Ambiente de Montaña y Regiones Áridas, Universidad Nacional de Chilecito, La Rioja, Argentina
}

The following two new species of Culicoides from the Argentinean Yungas are described, illustrated and placed to subgenus or species group and compared with related congeners: Culicoides calchaqui Spinelli \& Veggiani Aybar and Culicoides willinki Spinelli \& Veggiani Aybar. Culicoides daedaloides Wirth \& Blanton is recorded for the first time for Argentina and Culicoides pseudoheliconiae Felippe-Bauer is firstly mentioned from the northwestern region of the country.

Key words: Culicoides - C. calchaqui sp. nov. - C. willinki sp. nov. - new records - Yungas - Argentina

The genus Culicoides is by far the most notorious of the 109 extant genera of Ceratopogonidae. Not only is it the most diverse in the family, with 1,366 named species (Borkent 2012), but members occur virtually throughout the terrestrial world, from the tropics to far southern and northern areas, from coastal areas to very high altitudes (up to 4,200 m) (Spinelli \& Borkent 2004). Many species in the genus are miserable pests of humans and domestic animals, acting as vectors of a variety of diseases summarised by Borkent and Spinelli (2007). Of the 280 currently recognised Neotropical species, 42 inhabit Argentina and three more are known to occur in bordering sites of Uruguay and Paraguay.

The study of Culicoides specimens collected by researchers of the Institute of Entomology Dr Abraham Willink, Tucumán, Argentina, in the Yungas of northwestern Argentina, revealed the presence of two new species and an additional two species not recorded yet in the area. The purpose of this paper is to provide the descriptions and records of this material.

\section{MATERIALS AND METHODS}

All specimens, mounted on microscope slides in Canada balsam, were examined and measured with a binocular compound microscope at 40-400X. Photographs were taken with a digital camera Micrometrics SE Premium through a Nikon Eclipse E200 binocular microscope.

Terms for structures follow those used in the Manual of Central America Diptera (Brown et al. 2009). Names of veins are always in upper case and those of cells in lower case. Pale areas in cell $\mathrm{r}_{3}$ posterior to or immediately distal to the second radial cell are called poststigmatic pale spots. Ratios used follow Spinelli and Borkent (2004).

doi: 10.1590/0074-0276108052013008

+Corresponding author: spinelli@fcnym.unlp.edu.ar

Received 31 October 2012

Accepted 12 March 2013
Specimens are deposited in the collections of the Institute-Foundation Miguel Lillo (IFML), San Miguel de Tucumán, Argentina, and a paratype of C. calchaqui in the La Plata Museum (MLP), La Plata, Argentina.

\section{RESULTS}

Culicoides (Hoffmania) calchaqui

Spinelli \& Veggiani Aybar, sp. nov.

(Figs 1-4)

Diagnosis - Only Neotropical species in the guttatus species group with slender third palpal segment bearing subdivided pit, crossvein $\mathrm{r}-\mathrm{m}$ faintly darkened anteriorly, $\mathrm{R}_{3}$ faintly darkened up to the point where it turns abruptly forward to meet costa, two distal pale spots in $\mathrm{m}_{1}$, apical one faint, distal pale spot in $\mathrm{m}_{2}$ small and barely abutting wing margin, pale spot in cua small and separated from pale line bordering lower margin of $\mathrm{CuA}_{1}$ and apex of $\mathrm{CuA}_{2}$ dark.

Female - Head (Fig. 1): dark brown. Eyes bare, contiguous by distance equal to diameter of two ommatidia. Flagellum brown, bases of flagellomeres pale; AR 1.08$1.14(1.11, \mathrm{n}=3)$; sensilla coeloconica on flagellomeres 1, 9-13. Palpus (Fig. 2) dark brown; segment 3 elongate, slender, slightly swollen at midlength, with subdivided pit, long slender portion beyond pit; PR 3.60-3.84 (3.64, $\mathrm{n}=3)$; $\mathrm{P} / \mathrm{H}$ ratio $1.03-1.11(1.06, \mathrm{n}=3)$. Mandible with $17-19(\mathrm{n}=3)$ teeth.

Thorax: uniformly dark brown. Legs dark brown; fore, mid knees, broad base and apex of hind tibia pale; hind tibial comb with six spines, second from spur longest. Wing (Fig. 3) length 1.23-1.58 $(1.39, \mathrm{n}=3) \mathrm{mm}$; width 0.55-0.65 $(0.60, \mathrm{n}=3) \mathrm{mm}$; CR 0.66-0.69 (0.68, $\mathrm{n}=3$ ); with contrasting pattern; crossvein $\mathrm{r}-\mathrm{m}$ faintly darkened anteriorly; most of second radial cell in pale spot; $\mathrm{R}_{3}$ faintly darkened up to the point where it turns abruptly forward to meet costa; distal pale spot in $r_{3}$ transverse, reniform, barely abutting wing margin; $\mathrm{M}_{2}$ straddled by pale spot nearly its midlength; two distal 
pale spots in $\mathrm{m}_{1}$, apical one faint, abutting wing margin; distal pale spot in $\mathrm{m}_{2}$ small, rounded, barely abutting wing margin; pale spot in cua ${ }_{1}$ small, rounded, separated from pale line bordering lower margin of $\mathrm{CuA}_{1}$; anal cell with two basal, two distal pale spots; apices of $M_{1}, M_{2}$, $\mathrm{CuA}_{1}$ with small pale spot, apex of $\mathrm{CuA}_{2}$ dark; pale spot posterior to medial fork broadly connected with pale spot lying anterior to cubital fork. Macrotrichia scattered on distal fourth of wing, also present in cua ${ }_{1}$, anal cell. Halter brown.

Abdomen: dark brown. Two ovoid spermathecae without short necks (Fig. 4), measuring 58-66 $(62, \mathrm{n}=2)$ by $41-43(42, n=2) \mu$ and $41-65(53, n=2)$ by $35-43(39$, $\mathrm{n}=2) \mu$; rudimentary third, ring present.

\section{Male - Unknown}

Type data and depository - Holotype, Argentina, Tucumán, Lules, Potrero de las Tablas, 22-IV-2008, C. Veggiani Aybar, CDC light trap with $\mathrm{CO}_{2}$ (IFML).

Other material examined - Two female paratypes, as follows: same data as holotype, 1 female; Tucumán, Chicligasta, El Molino, 23-X-2010, 1 female, ultraviolet light trap (MLP).
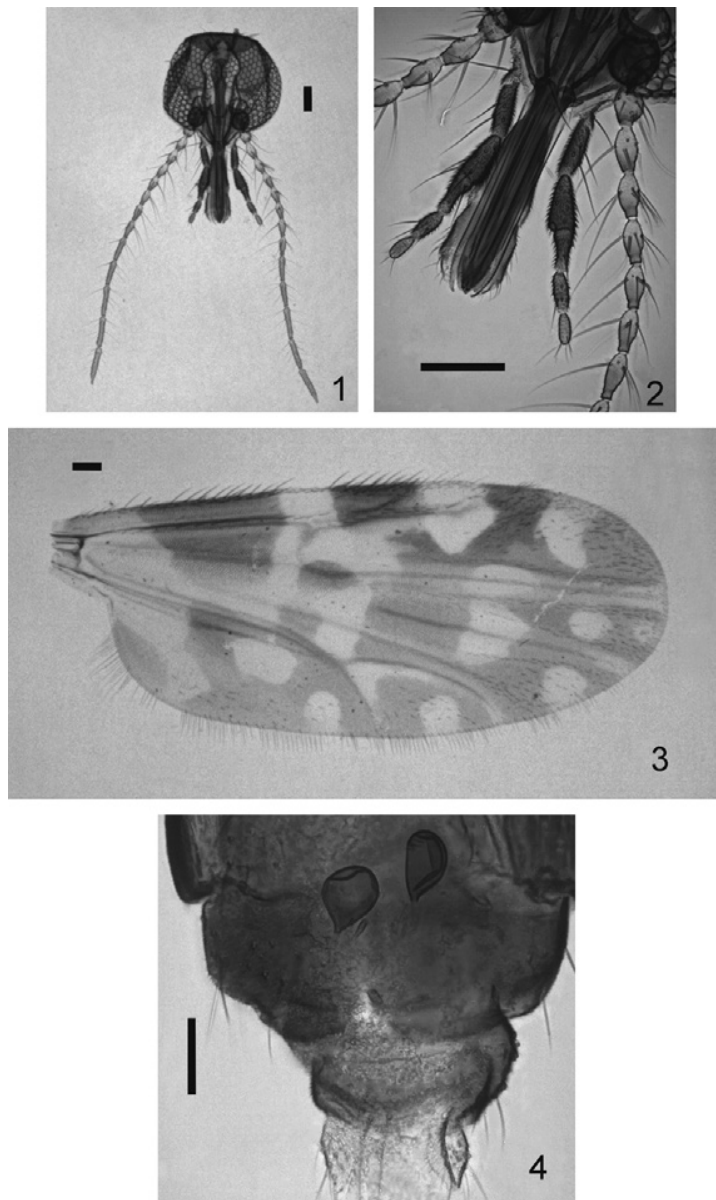

Figs 1-4: Culicoides calchaqui, female. 1: head; 2: palpus; 3: wing; 4: tip of abdomen, showing spermathecae. Bars $=0.05 \mathrm{~mm}$.

\section{Distribution - Argentina (Tucumán).}

Etymology - The species name is a reference to the Calchaquí Indians, early inhabitants of the type-locality and surrounding area.

Taxonomic discussion - C. calchaqui is a member of the guttatus species group within the subgenus Hoffmania Fox. It keys out in the Spinelli et al. (1993) revision of the Neotropical species of the guttatus group to the couplet 29 and would run to Culicoides ignacioi Forattini from southeastern Brazil and Paraguay and Culicoides paraignacioi Spinelli from Belize to Perú, French Guiana and Brazilian Amazonia. However, C. ignacioi is a much darker species, the third palpal segment is stouter in mid portion and the distal extension beyond the irregular pit is distinctly shorter, the mandible is armed with 20-22 teeth, the wing pattern is deeply contrasting, the crossvein $\mathrm{r}-\mathrm{m}$ is heavily dark anteriorly, the $\mathrm{R}_{3}$ is completely pale and the apical pale spot in cell $\mathrm{m}_{1}$ is well defined and broadly abuts the wing margin. C. paraignacioi is a smaller species, its third palpal segment is more slender with a definite, rounded and shallow sensory pit, the mandible bears $21-23$ teeth, the crossvein r-m is heavily dark anteriorly and the macrotrichia in cell cua ${ }_{1}$ and anal cell is restricted to the wing margin.

It also keys out in the Spinelli et al. (2005) revision of bloodsucking biting midges of Argentina to the couplet 24, but in this new species the vein $R_{3}$ is not pale, but darkened up to the point where it turns abruptly forward to meet the costa and lacks the distinct black spot just beyond apex.

This new species is also very similar to Culicoides annettae from Costa Rica (Spinelli \& Borkent 2004), but the latter species is smaller (wing length 0.94-1.14 mm), the $r-m$ crossvein and vein $R_{3}$ are not faintly darkened, the distal pale spot in cell $\mathrm{m}_{2}$ is larger and broadly abuts the wing margin, the pale spot in cell cua is connected with the pale line that borders lower margin of vein $\mathrm{CuA}_{1}$ and the apex of vein $\mathrm{CuA}_{2}$ is included in a small pale spot.

Culicoides willinki Spinelli \& Veggiani Aybar, sp. nov. (Figs 5-12)

Diagnosis - Only species in the limai species group with poststigmatic pale spots L-shaped nearly isolating a small dark spot at tip of second radial cell, distal pale spots in $\mathrm{r}_{3}$ and $\mathrm{m}_{1}$ small and separated from wing margin and macrotrichia mainly present marginally. Male tergite 9 with minute apicolateral processes, parameres without ventral lobe and aedeagus Y-shaped with distal portion slender, tapering to blunt tip flanked by prominent pair of slender pointed processes which borne distally in the basal arch.

Male - Similar to female with usual sexual differences. Wing length $0.70 \mathrm{~mm}$; width $0.32 \mathrm{~mm}$; CR 0.57 . Genitalia (Figs 5, 6): tergite 9 broad, tapering, distal margin with distinct median notch, apicolateral processes minute; sternite 9 with moderate posteromedian, rounded excavation. Gonocoxite elongate, $2.3 \mathrm{X}$ longer than greatest breadth, ventral root slender, foot-shaped, dorsal root slender, pointed; gonostylus $0.8 \mathrm{X}$ longer than gonocoxite, curved, tip pointed. Parameres (Fig. 5) separate, each with sclerotised basal knob, stem sinuose 
without ventral lobe, tapering to fine point with sublateral barbs. Aedeagus (Fig. 6) Y-shaped, lateral arms strongly sclerotised; basal arch triangular, extending $2 / 3$ of total length; distal portion slender, tapering to blunt tip flanked by prominent pair of slender pointed processes which borne distally in the basal arch.

Female - Head (Fig. 7): dark brown. Eyes bare, very narrowly separated. Flagellum pale brown; flagellomeres 2-8 vasiform, 9-13 subcylindrical; AR 0.94; sensilla coeloconica on flagellomeres 1, 5-8. Palpus (Fig. 8) brown, segment 3 swollen up to apex, with broad, shallow subapical pit; PR 1.73; P/H ratio 0.74. Mandible with 14 teeth.

Thorax: scutum (Fig. 9) dark brown with two elongate, anterior, submedian yellowish patches, two pairs of anterolateral small spots; scutellum narrowly dark brown mesally, pale on sides. Legs (Fig. 10) dark brown; tibiae with subbasal pale rings, broad apex of hind tibia pale, fore and midfemora with subapical pale rings; hind tibial comb with four spines, one nearest spur longest. Wing (Fig. 11) length $0.79 \mathrm{~mm}$; width $0.38 \mathrm{~mm}$; CR 0.59; second radial cell, distal third of first radial cell in dark spot; pale spot over r-m crossvein broadly abutting wing margin; poststigmatic pale spots in $r_{3}$ fused, L-shaped, nearly isolating a small dark spot at tip of second radial cell; distal pale in $\mathrm{r}_{3}$ small, not abutting anterior wing margin; $m_{1}$ with two small pale spots, distal one well separated from wing margin; $\mathrm{m}_{2}$ with two distal pale spots, most distal one small, rounded, barely abutting wing margin; cua ${ }_{1}$ with rounded pale spot broadly abutting wing margin and distal half of $\mathrm{CuA}_{j}$; anal cell with two large distal pale spots; $m_{2}$ with pale spot behind medial fork. Scattered macrotrichia only present marginally along entire wing, few accompanying distal fourth of $\mathrm{M}_{1}, \mathrm{M}_{2}$. Halter pale brown.
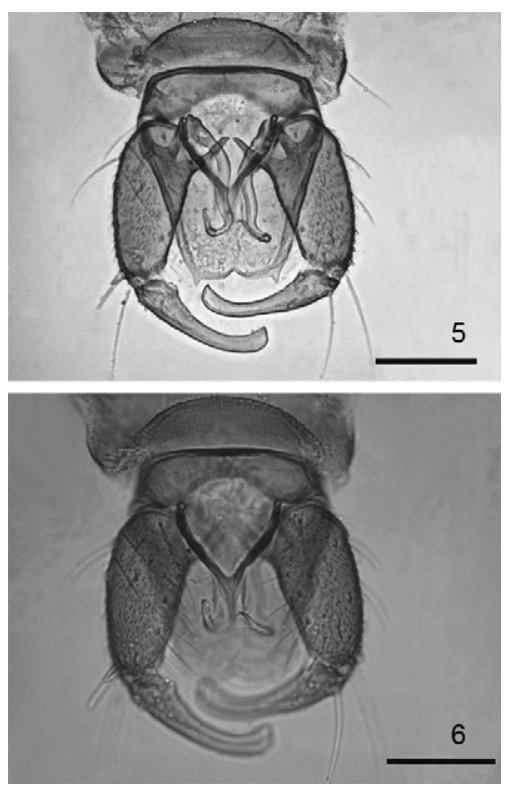

Figs 5, 6: Culicoides willinki, male; 5: genitalia (dorsal view); 6: genitalia (ventral view). Bars $=0.05 \mathrm{~mm}$.
Abdomen: brown, slightly darker at tip. Two subequal spermathecae, partially collapsed in the available specimen, necks moderately long (Fig. 12), each measuring 45 by $30 \mu$, neck $8 \mu$; rudimentary third, ring present.

Type data and depository - Holotype male, Argentina, Tucumán, Monteros, Reserva provincial La Florida, 04-XI-2005, MJ Dantur Juri, CDC light trap with $\mathrm{CO}_{2}$ (IFML).

Other material examined - One female paratype, same data as holotype.

Distribution - Argentina, known only from the typelocality in Tucumán.

Etymology - We are pleased to name this species after the late Dr Abraham Willink, teacher and advisor of many Argentinean entomologists working at the Institute of Entomology, College of Natural Sciences and IFML.

Taxonomic discussion - This new species belongs to the limai species group. It keys out in Spinelli et al. (2005) to the couplet 38 and would run to Culicoides limai Barretto from El Salvador to northeastern Argentina and Culicoides boliviensis Spinelli and Wirth from Bolivia, southern Brazil and northeastern Argentina. However, these two species lack the small, isolated dark spot at tip of second radial cell within the fused poststigmatic pale spots and as it is common in the majority of the members of the limai group, the pale
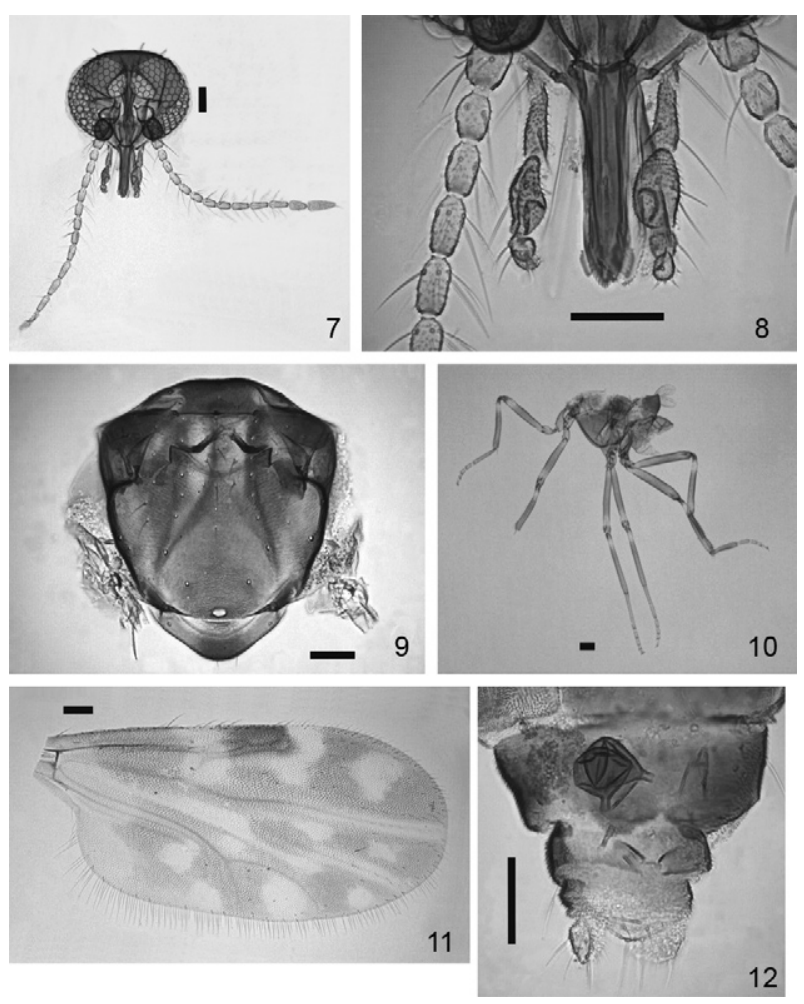

Figs 7-12: Culicoides willinki, female; 7: head; 8: palpus; 9: scutum and scutellum; 10: legs; 11: wing; 12: tip of abdomen, showing spermathecae. Bars $=0.05 \mathrm{~mm}$. 
areas in cells $\mathrm{r}_{3}, \mathrm{~m}_{1}, \mathrm{~m}_{2}$ and cua $\mathrm{a}_{1}$ are very extensive and the distal ones broadly abut the wing margin. The male genitalia of C. limai differs from $C$. willinki by the larger apicolateral processes, by the distinct ventral lobe of the paramere stem and by the aedeagus with rounded basal arch lacking the pair of prominent, slender and pointed processes that flank the aedeagus tip. The male of $C$. boliviensis is unknown.

Culicoides santanderi Browne from Colombia is also similar to C. willinki by virtue of the pale areas in the wing not so extensive and by the presence of a small, isolated dark spot at tip of second radial, but in this species the distal pale spots in cells $\mathrm{r}_{3}, \mathrm{~m}_{1}, \mathrm{~m}_{2}$ also abut the wing margin (very narrowly in $\mathrm{m}_{1}$ ), the halter is pale and the hind tibia exhibits a subapical pale ring.

New records

$$
\begin{aligned}
& \text { C. daedaloides Wirth \& Blanton } \\
& \text { (daedalus species group) }
\end{aligned}
$$

C. daedaloides Wirth \& Blanton (1959): 330 (male, female; Panama); Wirth (1974): 37 [in catalog south to the United States of America (USA)]; Barreto (1986): 149 (Colombia record); Wirth et al. (1988): 28 (numerical characters; wing photo; distr.); Borkent and Wirth (1997): 66 (in World catalog); Borkent and Spinelli (2000): 38 (in catalog south to the USA); Borkent and Spinelli (2007): 71 (in Neotropical catalog); Borkent (2012): 79 (in World catalog).

New record from Argentina - Argentina, Salta, Orán, Aguas Blancas, 13-III-2004, MJ Dantur Juri, two females, $\mathrm{CDC}$ light trap with $\mathrm{CO}_{2}$ (IFML).

Distribution - Panamá, Colombia, northwestern Argentina.

\section{Culicoides (Hoffmania) pseudoheliconiae Felippe-Bauer (hylas species group)}

C. pseudoheliconiae Felippe-Bauer, in Felippe-Bauer et al. (2008): 260 (female; Peru); Felippe-Bauer et al. (2009): 852, 856 (in key hylas group; Argentina record, Puerto Iguazú); Borkent (2012): 96 (in World catalog).

New record from northwestern Argentina - Argentina, Tucumán, Monteros, Reserva provincial La Florida, 04-XI-2005, MJ Dantur Juri, three females, CDC light trap with $\mathrm{CO}_{2}$ (IFML).

Distribution - Peru and northern Argentina.

\section{REFERENCES}

Barreto MD 1986. Catálogo de los Culicoides (Diptera: Ceratopogonidae) de Colombia. Colomb Med 17: 140-150.

Borkent A 2012. World species of biting midges (Diptera: Ceratopogonidae). Available from: inhs.uiuc.edu/research/FLYTREE/CeratopogonidaeCatalog.pdf.

Borkent A, Spinelli GR 2000. Catalog of New World biting midges south of the United States (Diptera: Ceratopogonidae). Contrib Ent Internatl 4: 1-107.

Borkent A, Spinelli GR 2007. Neotropical ceratopogonidae (Diptera: Insecta). In J Adis, JR Arias, G Rueda-Delgado, KM Wantzen, Aquatic biodiversity in Latin America (ABLA), Vol. 4, Pensoft, Sofia, p. 1-198.

Borkent A, Wirth WW 1997. World species of biting midges (Diptera: Ceratopogonidae). Bull Am Mus Nat Hist 233: 1-257.

Brown BV, Borkent A, Cumming JM, Wood DM, Woodley NE, Zumbado MA 2009. Manual of Central American Diptera, Vol. 1, NRC Research Press, Ottawa, p. 1-714.

Felippe-Bauer ML, Cáceres AG, Silva CS, Valderrama-Bazan W, Gonzales-Perez A, Costa JM 2008. Description of Culicoides pseudoheliconiae sp.n. from Peruvian Amazon and revalidation of Culicoides contubernalis Ortiz \& León (Diptera: Ceratopogonidae). Mem Inst Oswaldo Cruz 103: 259-262.

Felippe-Bauer ML, Damasceno CP, Py-Daniel V, Spinelli GR 2009. Culicoides baniwa sp.nov. from the Brazilian Amazon Region with a synopsis of the hylas species group (Diptera: Ceratopogonidae). Mem Inst Oswaldo Cruz 104: 851-857.

Spinelli GR, Borkent A 2004. New species of Central American Culicoides Latreille (Diptera: Ceratopogonidae) with a synopsis of species from Costa Rica. Proc Entomol Soc Wash 106: 361-395.

Spinelli GR, Greiner EC, Wirth WW 1993. The Neotropical bloodsucking midges of Culicoides guttatus group of the subgenus Hoffmania (Diptera: Ceratopogonidae). Contributions of the American Entomological Institute 27: 1-91.

Spinelli GR, Ronderos MM, Díaz F, Marino PI 2005. The bloodsucking biting midges of Argentina (Diptera: Ceratopogonidae). Mem Inst Oswaldo Cruz 100: 137-150.

Wirth WW 1974. Family Ceratopogonidae. In N Papavero, A catalog of the Diptera of the Americas south of the United States, Fasc. 14, Museu de Zoologia, São Paulo, p. 1-89.

Wirth WW, Blanton FS 1959. Biting midges of the genus Culicoides from Panama (Diptera: Heleidae). Proceedings of the United States National Museum 109: 237-482.

Wirth WW, Dyce AL, Spinelli GR 1988. An atlas of wing photographs: with a summary of the numerical characters of the Neotropical species of Culicoides (Diptera: Ceratopogonidae), 1st ed., Vol. 25, American Entomological Institute, Gainesville, 72 pp. 